been staying for ten days in London, and two long white paraffin candles have been standing on the drawing-room chimney-piece all the time. We have not been using the candles; but the wicks were ignited before we came to the rooms, as it is very common to do with new candles. I noticed two days ago that the wicks were all covered over with what I at first took to be some kind of mouldy growth, but what I now find is dust which has attached itself in fine hair-like tufts to the wicks of the candles, sticking out in all directions exactly like the tufts of iron filings on a powerful magnet.

I am well acquainted with this phenomenon in the vicinity of an electric machine which is kept working continuously. For example, we find it constantly in the neighbourhood of the electrifying machine of Sir W. Thomson's siphon-recorder, where the insulating supports collect great quantities of dust, and generally in these curious forms. From the appearance of the deposits on the wicks of the candles I have very little doubt that somehow or other electric attraction has played an important part in the collecting of the dust and the formation of the filaments. But whence the electrification has come I am unable to say, unless it be that a warm current of air, which $I$ find is always passing upwards past the candles from a wooden mantelpiece warmed by the fire, electrifies the paraffin candles and causes the phenomenon I have described.

39, Eastbourne Terrace, London, W.,

$$
\text { J. T. BOTTOMLEY }
$$

\title{
Simson's Line
}

Mr. J. S. MACKay of the Edinburgh Academy, though not able to trace "Simson's line" to Simson's works (see my notice of Dr. Casey's " Euclid," Nature, October 23, p. 607), has furnished me with the following account, which may be of general interest:- "The theorem that the orthogonal projections of a point on the circumference of a circle upon the sides of an inscribed circle are collinear is ascribed to Robert Simson by Catalan in his 'Théorèmes et Problèmes de Géométrie Élémentaire,' and he speaks several times of 'la droite de Simson.' This book of Catalan's is, I fancy, better known in the United Kingdom than many other Continental works where the same statement is made; and I conjecture that we have adopted the name from Catalan. It may, however, be the case that we have taken the information from Poncelet's 'Propriétés Projectives,' $\S 468$, where it is said that Servois attributes the theorem to $R$. Simson. The passage where Servois makes this ascription occurs in Gergonne's 'Annales de Mathématiques,' vol. iv. p. 250, and it is unsatisfactory enough: 'I a méthode qui vient d'être indiqué plus haut pour déterminer le point $\mathrm{C}$ repose sur le théorème suivant, qui est, je crois, de Simson.' I cannot carry the ascription of the theorem to Simson farther back than to Servois, and though I am not positive that Servois has made a mistake, yet I think it highly probable. The extension of the theorem to the oblique projections is attributed by Catalan to Chasles. It is due to Poncelet, and is given in the section quoted above."

October 27

\section{A Rainbow after Sunset}

ON the evening of August 29 the almanac sunset for Ireland south is placed at $6 \mathrm{~h}$. $5 \mathrm{Im}$. Happening to look out to southsouth-east I saw a well-marked, though not very brilliant, portion of a rainbow in a shower cloud just above the horizon. It was not a perfect bow, but what sailors call $a$ dog. I looked at the clock and saw that it was 7.15 p.m. Knowing that the sun had set, and being curious to see what could have produced the bow, I immediately went out and examined the western sky. The sun had indeed set, but there was a bright red glow and some flocculent clouds were tinged strongly with a brilliant rosy red. It was plain that the rainbow was caused by reflectcd light.

Stonyford, Co. Kilkenny

James Graves

\section{TROPICAL AFRICAN MOUNTAIN FLORA}

A VERY interesting collection of plants has been A brought to Kew by that intrepid African explorer Mr. Joseph Thomson, made during his late journey into the Masai country. They have been examined by Prof. Oliver, and consist of about thirty-five species from Kili-

manjaro at 9000 to 10,000 feet of elevation; a few from a crater near Lake Nairasha at 7000 to 8000 feet elevation; thirty-four from the Kapté plateau at 5000 to 6000 feet ; and fifty-eight from Lykipia at 6000 to 8000 feet.

These collections exhibit the mingling of North Temperate types with others characteristic of Southern Africa, for which previous discoveries had prepared us. Of these the most interesting are, as new to Tropical Africa, an Anemone, a Delphinium (very different from the Abyssinian D. dasycaulon), and a Cerastium of remarkable habit. Of South African forms the most striking is the handsome arborescent Rutaceous plant, Calodendron capense, the "wild chestnut" of Natal, to the north of which it had not previously been found. Of northern forms is a Juniper, another genus unknown to Tropical Africa, and which was found forming groves at an elevation of 6000 to 8000 feet, and itself attaining a height of 100 feet ! it is the $J$. procera of Abyssinia. A Podocarpus gathered along with the Juniper, and also attaining roo feet in height, is probably the $P$. elongata of Abyssinia, which, or a near ally, also occurs in South Africa. The only other Conifer previously found in the equatorial regions of Africa is the Podocarpus Mannii from the peak of St. Thomas in the Gulf of Guinea.

J. D. HOOKER

\section{AN ELECTKO-DYNAMOMETER WITH}

EXTREMELY I.IGHT SUSPENDED COIL

I $N$ my former communications to NATURE it has, I believe, appeared (I) that the induction currents used by Du Bois-Reymond, Duchênne, and other observers for physiological and therapeutical purposes were only arbitrarily and very insufficiently measured; (2) that the simplest and most practical instrument for their measurement is a delicate electro-dynamometer ; (3) that in consequence of their extreme smallness, every available method must be employed to reduce the sluggishness of such an instrument without impairing its accuracy ; (4) that an instrument of this character, shown by me before the Physical Society at Oxford in June 1882, had answered very well, indeed better than a more expensive apparatus designed by Prof. Kohlrausch for larger currents.

It was, however, objected that there is an insurmountable difficulty in keeping a good contact between the aluminium and silver-gilt wires used in it for suspended coil and suspending wire respectively.

At the British Association meeting in Montreal I was able to show an improved form of the contrivance, in which this difficulty was surmounted; and, in addition, a method of damping the oscillations, which, while improving the insulation, cnabled the weight of the suspended coil, on which the force of the torsion couple depends, to be varied between limits practically infinite.

The contact difficulty is met by taking a small plate of ebonite $3 \mathrm{~mm}$. by $5 \mathrm{~mm}$. in sizc, and tapping into it two small gold screws, long enough to project through, and carry two little nuts on the opposite sides. To the two screw heads the ends of the aluminium coil, bent into rings and filed flat, are firmly screwed; under the two nuts are twisted the ends of the gilt-silver suspension wires; the nuts are then similarly screwed home. Ebonite is elastic enough to render the junction air- and fluidproof.

The second requirement was attained by coiling the aluminium wire on a thin tube of cork, and immersing it in a vessel filled with petroleum oil. Aluminium is about two and a half times heavier than water, nearly three times the specific gravity of this oil; whercas cork floats on it. Consequently, by properly proportioning the amount of cork relatively to the wire coiled on it, any desired specific gravity from absolute flotation to that of aluminium itself can be obtained. It is even practicable to load the coil, like a Sykes's hydrometer, by dropping 